\title{
Urban Citizenship: Spaces for Enacting Rights
}

\author{
Kathrin Wildner
}

In autumn 2015, one of many demonstrations in Hamburg caught my particular attention. It was not so much the size of the 'Never Mind the Papers' demonstration that was impressive, it was the dynamics: the broad range of participants, the diversity of languages, posters and signs. It was the first sizeable demonstration that came at the end of the 'long summer of migration' (see Hess et al. 2016). The protest was organized by a coalition of the refugee movement and its supporters, including many newcomers, refugees and migrants who lived in Hamburg. After the first month of a collapsing border regime with people continuously arrivingcrossing the Mediterranean Sea and national borders in Eastern Europe (Hess et al. 2016, p. 6) - a fairly intense state of emergency was present in most big cities within (northern) Europe. Receiving thousands of people daily led to a lack of shelter and basic provisions. At the same time, an incredible mobilization of voluntary support and solidarity substituted or supplemented the failing local institutions (Mokre 2015). By November 2015 , the situation was slowly changing; the initial days of emergency were left behind and everyday life had to be faced. The newly arrived began organizing with other groups of refugees and migrants and engaging

K. Wildner $(\bowtie)$

HafenCity University Hamburg, Hamburg, Germany

e-mail: wildner@hcu-hamburg.de

(C) The Author(s) 2019

P. Hildebrandt et al. (eds.), Performing Citizenship, Performance

Philosophy, https://doi.org/10.1007/978-3-319-97502-3_10 
more directly with the city. This also involved claiming their rights to social and political participation. Political participation in this compilation is discussed as one of the conditions for citizenship; this is precisely how I would like to frame it here: citizenship not as a formal, institutional and normative arrangement made by national governments, but as an active process of doing and negotiating, performed by diverse groups claiming the right to participate (see Isin 2017; Cvejic and Vujanovic 2015; Lebuhn 2013).

At the time of the refugee struggle, I was involved in a project on urban learning. The metroZones school of urban action ${ }^{2}$ was a self-organized, model project for political education and critical urban reflection; a think-tank for perception and discussion, for theory and urban debates, for practical tools and urban interventions. Focusing on questions surrounding the production of urban space, the refugee movement was an important aspect-looking at the ways in which new forms of appropriation, negotiation and citizenship in urban space were invented and, in diverse ways, leading to a re-politicization of the urban debate (Hess and Lebuhn 2014, Lanz 2015, p. 487).

Based on the hypothesis that citizenship is a performative act (Isin 2017, p. 501ff.), I would like to have a closer look at the spatial conditions for acts of citizenship: How and which kinds of urban situations can facilitate or prevent accessibility to the city? Are there possible spaces where citizenship might be provided or invented? How can citizenship be performed? Are there certain tools, skills and expertise required in performing citizenship? And if there are certain spaces which might facilitate practices of citizenship, how can citizenship be enacted in those spaces? How can citizenship as a practice be learned?

What role could the metro Zones school for urban action play in providing space and tools for debates and interventions to politicize the urban?

In order to reflect on some of these questions, I will focus on a certain moment and discussion of the metroZones school for urban action. The text is a compilation of questions and ideas connected to each other; it is not a finished analysis. In the same way, the drawings by artist Eric Göngrich are to be read as graphic comments, in dialogue with the text (Fig. 1). ${ }^{3}$

\section{The metroZones SCHOOL FOR URBAN ACtion}

The metroZones school for urban action was born out of cooperation between the Hamburg-based initiative dock europe and metroZones-center of urban affairs from Berlin. Over a period of two years, a wide range of 


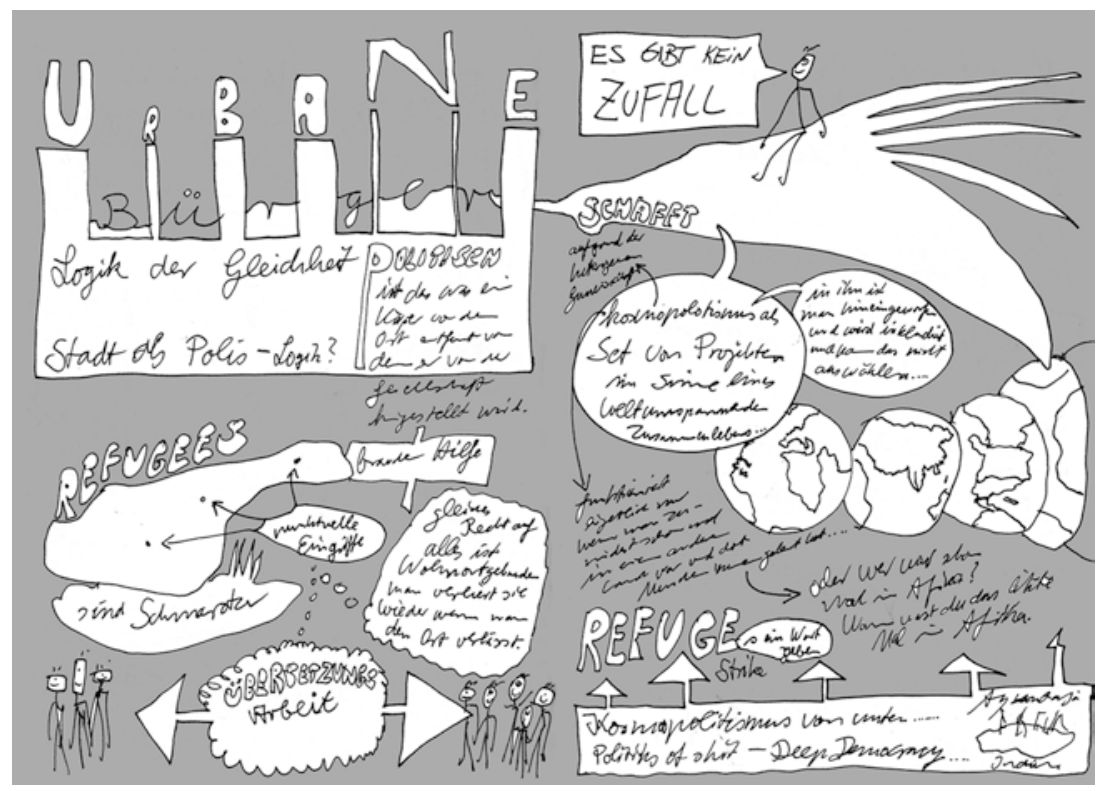

Fig. 1 This work by Eric Göngrich comments on the diverse claims of a cosmopolitical city and the right to public space, interpreting the everyday practices of refugees as political protest. (metroZones school for urban action, November 2015)

urban actors, activists and other urban citizens met in Berlin und Hamburg to discuss, and put into practice, a number of conceptual ideas and methodological tools from critical urban studies for the purpose of urban explorations and interventions beyond academia. ${ }^{4}$

Therefore, the school actively oriented itself towards those urban dwellers and activists who were curious to think about urban practices in dialogue, to learn from one another in order to connect various urban skills, experiences and expertise. Understanding the city as a cosmo-polis, made up of people arriving from very different global contexts, we asked ourselves how negotiate spaces of acting and belonging. Urban action here is understood in the sense of the German term Handeln; it refers to the act of negotiating, to be distinguished from working or producing. In the meaning of Hanna Arendt's concept of Handeln, acting is understood as a process of communication and primarily as a political interaction which takes place in public space (Arendt 1998). 
For six months, the participants of the metroZones school met continuously-at events such as public lectures, reading circles and discussion 'salons', partaking in practical exercises in workshop sessions and attending a four-day summer camp. The combination of theoretical and practical approaches, conceptual as well as methodological tools, exercises and performative enactments in public space, produced various formats and situations for collective reflection on urban experiences and practices. The questions and discussions revolved around issues of production and configuration of urban spaces on different scales: the effect of collective perceptions and actions on everyday life as well as the invention of strategies and tactics as modes of [urban] citizenship.

Crossing boundaries between disciplines - in the reclaiming of those border zones of context between everyday practices and activism, art and science, political and urban education-the metroZones school experimented with diverse formats of urban learning. We understand urban learning as meaning practices and interactions through which knowledge is created, contested and transformed (McFarlane 2011). This production of knowledge, which takes place beyond academic, cultural or education institutions, is seen as a collaborative process of self-empowerment. Densities, diversities and unsettledness - considered to be predominantly urban-are made productive. Therefore, urban learning needs to address different speeds, ways of speaking and body languages. Precisely through disruption - of routines, critical reflection on situations usually taken to be self-evident, attempts at de-normalization and alienation-potential for (social) change might emerge. This way, urban learning and knowledge production-useful in everyday practices as well as political actionbecome urban strategies in and of themselves.

Aside from questions of the potentials and limitations of the format of a school—with its corresponding hierarchies between lecturer and learner, classroom and public space-one of the main questions arising from our experiment was: how the school could position itself within pre-existing political structures, or as a political structure in its own right. Could the school provide a space to act as (urban) citizens?

\section{The Demonstration 'Never Mind the Papers'}

In November 2015, the alliance 'Right to the City - Never Mind the Papers' initiated a demonstration in Hamburg, focussing on the everyday situation and the necessity of political participation for the newly arrived. 
The call for the demonstration asserted that the basic condition of political participation was a human right equal to the right to adequate shelter, the right to work, access to education and medical care. ${ }^{5}$ Under the slogan 'Refugees Welcome means Equal Rights for All!', about 7000 people took part.

Months before the demonstration, the coalition of self-organized migrant groups and supporters concentrated on mobilizing people. Beside a series of networking and organizing meetings of the involved initiatives, inside the refugee camps, claims were discussed, slogans invented and posters created; speech workshops were organized to practise the use of microphones as well as shuttle buses to transport people from their accommodation so they might participate actively in the demonstration.

The demonstration 'Never Mind the Papers' in November 2015 coincided with the workshop weekend of the metroZones School for urban action in Hamburg. As the subject matter of the weekend involved reflection on public space and urban intervention (see Wildner 2003; Yudice 2005 ), the demonstration seemed to be a perfect source (and cause) to discuss and rehearse diverse aspects of urban action. Such questions arising
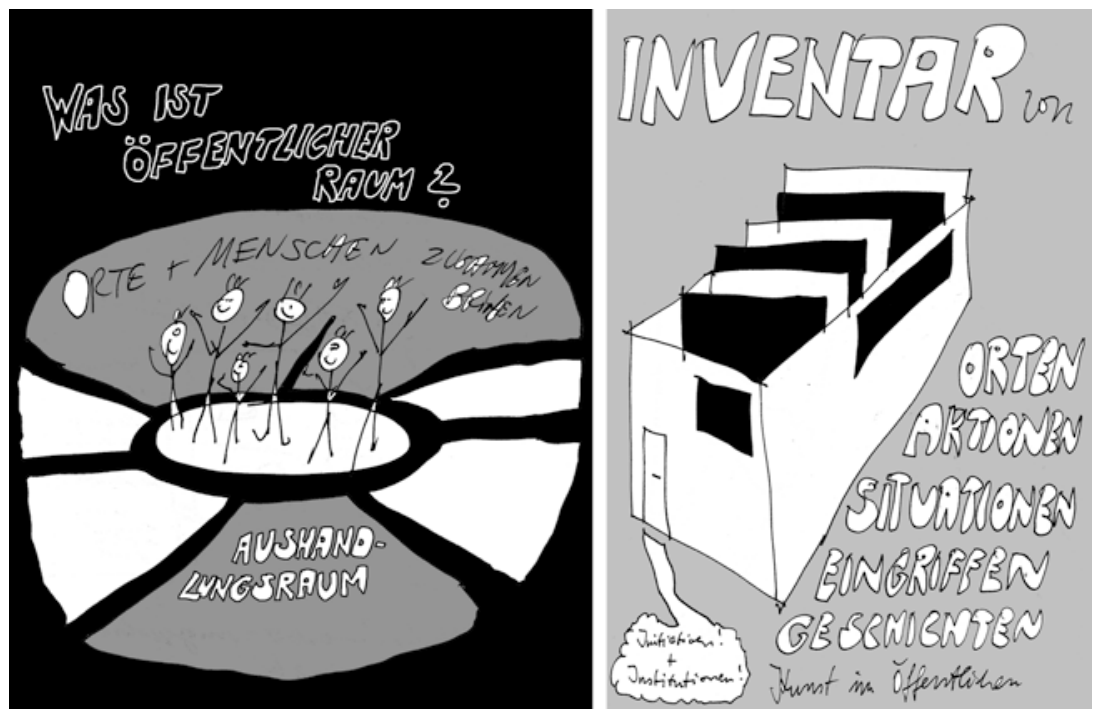

Figs. 2 and 3 Erik Göngrich visualizes public space as a fragmented space of negotiation, art in public space is seen as a box composed of practices, places, activities, situations, and stories. (metroZones school for urban action, November 2015) 
as: What is public space? What kind of tools and instruments might be helpful to intervene in public space? How can they be practised and implemented? (Figs. 2 and 3)

\section{Spaces and Strategies of Engagement}

By means of theoretical inputs and lectures, we started to have a closer look at various spatial settings and events, looking at discussion in public space as a mode of negotiation between contradictory positions (Delgado 1999; Wildner 2003). We identified the demonstration as a well-established means of public political intervention, whereby civil society practices collectivity on the streets and dissent is made visible. Alongside the discussion of concepts, a main focus for the school lay in identifying tools and practices to intervene or generate visibility in public space (Fig. 4).

At the school workshop, we split into three groups to work with different perspectives. One group decided to take the perspective of observation. Under the guidance of the cultural scientist Anne Huffschmid, this group prepared a series of questions and a variety of formats of notation (photography, mapping, use of note-taking, sound recording, in order to

Fig. 4 Eric Göngrich depicts urban

intervention as a rehearsal stage, a possibility or a city marketing process. (metroZones school for urban action, November 2015)

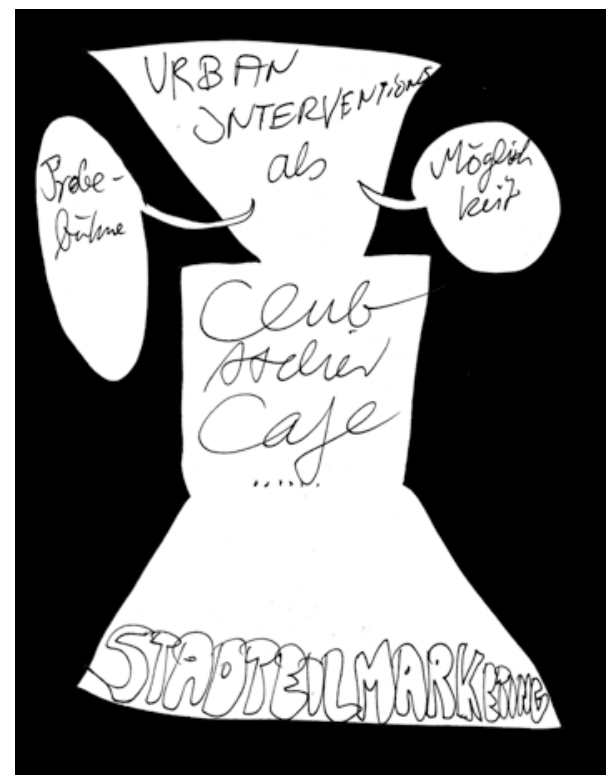


carry out participant observation at the demonstration. Spatial settings of the route and material elements (sound trucks, banners, posters) as well as slogans and shouting were registered-producing a kind of archive of collected of elements of protest culture, looking at participating groups and different ways to perform participation at the demonstration.

Who is giving a speech? About what, and where? Who is invited to talk? And who claims the right to speak?

The idea of this approach was to create a register that later could be used for a discourse-analytical observation, going beyond the concrete situation of the demonstration in Hamburg. The register of elements become a manifested inventory of politics of participation that is to be analysed in the contexts of ongoing conceptual debates on the potential and limits of urban citizenship (Lebuhn 2015) (Fig. 5).

A second group worked on the topic of performative speech-acts as interventions in public space. ${ }^{6}$ In this workshop, choreographer Liz Rech and mediator Petra Barz reflected on the performative aspects as corporal interventions in public space. Using examples of artistic urban interven-

Fig. 5 The drawing by Eric Göngrich evokes a mutual body, naming the collective dance as a political performative action. (metroZones school for urban action, November 2015)

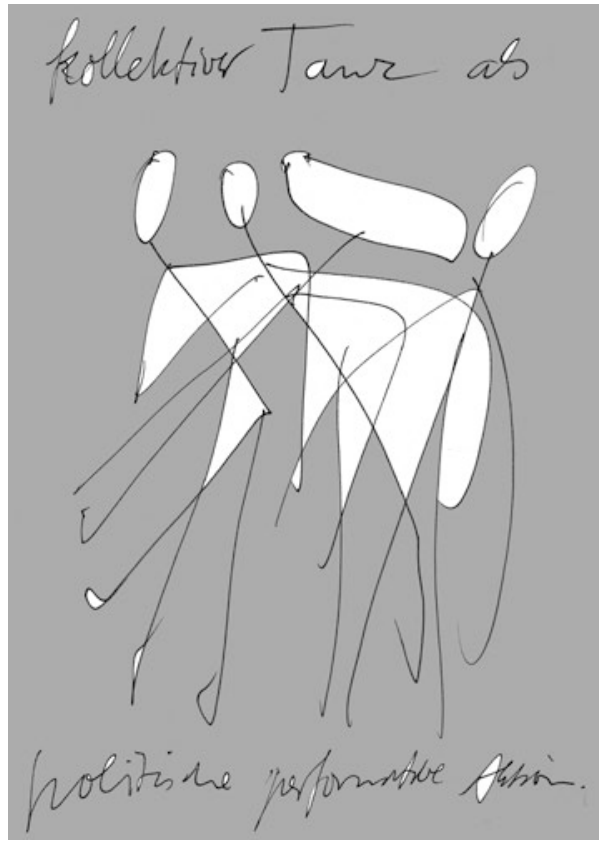


tion, they discussed the diversity of performances and activism conducted in public space. By way of practical input, they provided technical and vocal training. Some of the participants of the workshop were unused to speaking out loudly and, during the workshop, experienced their own voice in this way for the first time.

At the demonstration, some of the group took a closer look at the sound truck and the moderator group. This group not only moderated the well-prepared speeches by members of the diverse communities but, during the march, a mobile microphone was also used, allowing people on the street to participate by actively speaking of their situations-being given a voice and being heard. Through the school's exercise at the demonstration, participants experienced the importance of speech and bodily presence when participating politically in public space. Alongside achieving an experience of collectivity, this moment supported the individual presence in public space as an important moment of participation.

A third group on this weekend was guided by Erik Göngrich. ${ }^{7}$ As an architect and artist, Erik was especially interested to develop tools that utilized writing and drawing as material elements to intervene into public space. The workshop began with some drawing exercises, producing simple protest boards that participants then carried into the outside space.

What do I want to say? What happens if I carry my protest board-a slogan as a statement-into public space? How visible or vulnerable do I become?

Initially, the boards were tested out in the garden and streets around the workshop space, a cultural centre in Wilhelmsburg on the periphery of Hamburg. That Friday evening, the neighbourhood was characterized by everyday life, with no apparent reason for protest or demonstration. This meant that the action became something of an artistic intervention, which left some participants (a number of whom did not want to take their boards into public space) feeling even more vulnerable. This situation produced discussion full of controversy around the question of how the metroZones school could and should take part in the demonstration the next day. In particular, the meaning of intervention was discussed: What kind of slogans could be invented, which message would be appropriatedand, in particular, would it be a misuse of the refugee cause to make an intervention as a part of the metroZones school? Finally, some members of the group decided to go to the marketplace in the neighbourhood, talking to the people about the demonstration and the situation of the refugees, offering to write a message on a board composed by their conversation 
partners and bring it to the demonstration in the city centre the next day. Motivated by positive responses, eventually, the school's participants did indeed take part in the demonstration, bringing messages from the periphery of the city to the centre. Again, questions surrounding accessibility, visibility and possible acts of participation became subjects of discussion.

\section{Urban Citizenship Enacted}

The different examples of the metroZones school, in the context of the demonstration, showed certain conditions of negotiating urban space as moments of performing citizenship. Taking into account the idea that people become citizens through their participation in the conception, construction and negotiation of space (Irazabal 2008, p. 15), certain configurations of public space and elements for citizenship were pointed out.

We agree: People become citizens when they act as political subjects. One of the fundamental characteristics of a political subject is to make claims for rights (Isin 2017 , p. 501).

Hannah Arendt's phrase 'the right to have rights' (Arendt 1998), which addresses the right to be part of a political community, is here pushed further. The right to make claims for rights goes beyond the surface concessions of 'integration'. Instead, it marks an active positioning of the subject by way of doing things, such as claiming rights (Isin 2017).

In this sense, citizenship is not understood as a top-down arrangement made by national governments - so called 'paper citizenship'-but as an active process of doing and negotiating, in the sense of a performed citizenship (Isin 2017 , p. 504). Re-conceptualizing the notion of citizenship means shifting its centre from the state to the people; stressing pluralist models; and including participatory, inclusive and insurgent definitions of citizenship (Miraftab and Wills 2005, p. 202). This understanding of citizenship unfolds over time. Since we understand the moment of acting or engaging as a fundamental moment in which citizenship comes into play, we can define citizenship as a time-based and ongoing process of negotiation (see the introduction to this volume). Citizenship here is not a formal - but a substantive position - with bearing on an array of civil, political, social economic rights, including rights to shelter, water, education, and so on (Miraftab and Wills 2005, p. 201). At the same time, this concept of citizenship is not focused on an endpoint - the achieved status - but is a permanent debate, a temporary and changing condition, acted out in time and space. 
To understand the act of citizenship as a performative act, we have to look carefully at the time and space in which these performances are acted out, or in Isin's words, 'look at the performing acts through which people become citizens in exercising or claiming rights and duties' (Isin 2017, p. 520). A demonstration represents a temporary space in which citizenship is enacted as a right to speak and be heard, to participate, to be part of a multitude. The demonstration that came out of the refugee movement-discussed above-'Never Mind the Papers', provided such a space for those who are excluded from the basic rights of state citizenship. By performing speaking-acts on the street, they 'transform conventions by enacting provocative acts' (Isin 2017); the refugees' struggles for rights are made public. In this moment, re-politicizing the urban debate (Lanz 2015 , p. 487), they become citizens through their actions.

Here, public space comes into play: through the demonstration, participants collectively become manifest in urban space, turning the streets into a stage for their claims, visible for everybody to see, 'transform[ing] them into temporary places of urban citizenship' (Lanz 2016, p. 489). The appropriation of the streets by masses of people, right in the middle of Hamburg's downtown shopping district, waving colourful banners, shouting slogans and eliciting reactions from passers-by, succeeded in creating - despite the heterogeneity of the participants - at least a momentary sense of common struggle and collectivity.

Among urban practices, the demonstration is a ritualized and sometimes spectacular event. Following Engin Isin's argument for 'acts of citizenship as quotidian enactments, which might lack the visibility of certain performative acts but nevertheless can be consequential' (Isin 2017, p. 509), we might look in more detail to the collective appropriation of urban public spaces; for example, in the playing out around the tent of the 'Lampedusa in Hamburg' group at the central station, or the dynamics of the former self-organized refugee protest camp at Oranienplatz in Berlin (Fontanari 2016). In these cases, the everyday production of space in the city reflects a heterogeneous and diverse society, seemingly tying together those central elements of everyday practice that constitute possible versions of a continuous urban citizenship (Lanz 2015, p. 489). With the metroZones school for urban action, a situation was created to reflect upon urban spaces and urban citizenship as a localized practice. The school became a space to exchange experiences, reflect on activities, and discuss self-empowered political engagement, as well as a performative space for enacting urban citizenship. 


\section{Notes}

1. 'Never Mind the Papers' is a Hamburg-based network of refugee activists, supporters, the 'The Right to the City' movement, Union activists and other left-wing initiatives, all fighting for an accessible and just city for everybody. https://nevermindthepapers.noblogs.org, date accessed 13 March 2018.

2. The metroZones school of urban action is a two-year public founded project (2015-2016) conducted by the Berlin-based group metroZones - center for urban affairs - www.metrozones.info, date accessed 2 February 2018-and the Hamburg-based NGO dock europe-www.dock-europe.net, date accessed 2 February 2018.

3. For each workshop of the metroZones school, an artist was invited to protocol and comment the discussions by a kind of graphic record, see https:// schoolbook.metrozones.info, date accessed 2 February 2018. For this paper, I selected some drawings by the Berlin-based artist, Eric Göngrich. His drawings have a specific focus and narration, presenting his position as an observer of some moments of the metroZones school as well as an active participant of the situation: 'It is not so much about learning, but I try to understand through my drawings [...] I try to summarize the situation in a subjective and provocative way.' Eric Göngrich, https://vimeo. com/209878106, date accessed 2 February 2018 (translation by author).

4. The metroZones Schule für städtisches Handeln was financed for two years (2015-6) as a model project by the German Federal Institution Bundeszentrale für politische Bildung, see www.metrozones.info, date accessed 11 February 2018.

5. http://hh-mittendrin.de/2015/11/demo-fuer-gefluechtete-zeigendass-alle-menschen-in-hamburg-gleiche-rechte-haben, date accessed 10 January 2018.

6. For further information about the workshop, see Liz Rech (2015) 'Körper und Öffentlichkeit - zur performativen Dimension städtischen Handelns' in metroZones Schule für städtisches Handeln: 'Von der Situation zur Intervention - Zugänge und Stationen', https://www.metrozones.info/ wp-content/uploads/2016/08/mZ-Schule-fuer-staedtisches-HandelnDossier-2015.pdf, date accessed 10 January 2018.

7. The artist Erik Göngrich was invited to organize a workshop on drawing and artistic intervention in public space through objects. Additionally, he was invited to comment on the school workshop by taking minutes through the action of drawing; the graphic comments in this text thus arose in the framework of the School for urban action in the autumn of 2015. 


\section{REFERENCES}

Arendt, Hannah. 1998. The Human Condition. Chicago: University of Chicago Press.

Cvejic, Bojana, and Ana Vujanovic. 2015. Public Sphere by Performance. Berlin: b_books.

Delgado, Manuel. 1999. El Animal Public: Hacia una antropología de los espacios urbanos. Barcelona: Anagrama.

Fontanari, Elena. 2016. Looking for Neverland. The Experience of the Group "Lampedusa in Berlin" and the Refugee Protest of Oranienplatz. In Witnessing the Transition: Moments in the Long Summer of Migration, ed. Gökce Yurdakul et al., 15-35. Berlin: Assoziationen A.

Hess, Sabine, and Henrik Lebuhn. 2014. Politiken der Bürgerschaft. Zur Forschungsdebatte um Migration, Stadt und citizenship. Sub/urban 2 (3): $11-34$.

Hess, Sabine, et al. 2016. Der lange Sommer der Migration [The Long Summer of Migration]. Berlin: Assoziationen A.

Irazabal, Clara. 2008. Citizenship, Democracy, and Public Space in Latin America. In Ordinary Places, Extraordinary Events. Citizenship, Democracy, and Public Space in Latin America, ed. Clara Irazabal, 11-35. New York: Routledge.

Isin, Engin. 2017. Performative Citizenship. In Oxford Handbook of Citizenship, ed. Ayelet Shachar, Rainer Bauböck, Irene Bloemraad, and Maarten Vink, 500-523. Oxford: Oxford University Press.

Lanz, Stephan. 2015. Refugees und die Stadt. In The Dialogic City - Berlin Wird Berlin, ed. Arno Brandelhuber, Florian Herzwech, and Thomas Mayfried, 487-495. Berlin: Walter König.

Lebuhn, Henrik. 2013. Local Border Practices and Urban Citizenship in Europe. City: Analysis of Urban Trends, Culture, Theory, Policy, Action 17 (1): 37-51.

McFarlane, Colin. 2011. Learning the City. Knowledge and Translocal Assemblage. Oxford: Wiley-Blackwell.

Miraftab, Faranak, and Shana Wills. 2005. Insurgency and Spaces of Active Citizenship. The Story of Western Cape Anti-Eviction Campaign (AEC) in South Africa. Journal of Planning, Education and Research 25: 200-217.

Mokre, Monika. 2015. Solidarität als Übersetzung. Überlegungen zum Refugee Protest Camp Vienna. Vienna: Transversal.

Wildner, Kathrin. 2003. Public Space as a Space of Negotiation. http://eipcp.net/ transversal/1203/wildner/en. Accessed 15 Nov 2017.

Yudice, George. 2005. The Heuristics of Contemporary Urban Art Interventions. Public 32: 9-21. 
Open Access This chapter is licensed under the terms of the Creative Commons Attribution 4.0 International License (http://creativecommons.org/licenses/ by $/ 4.0 /$ ), which permits use, sharing, adaptation, distribution and reproduction in any medium or format, as long as you give appropriate credit to the original author(s) and the source, provide a link to the Creative Commons licence and indicate if changes were made.

The images or other third party material in this chapter are included in the chapter's Creative Commons licence, unless indicated otherwise in a credit line to the material. If material is not included in the chapter's Creative Commons licence and your intended use is not permitted by statutory regulation or exceeds the permitted use, you will need to obtain permission directly from the copyright holder.

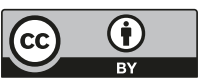

